\title{
Haplosporidium sp. (Alveolata: Haplosporidia) associated with mortalities among rock oysters Saccostrea cuccullata in north Western Australia
}

\author{
P. M. Hine*, Tina Thorne \\ Fish Health Section, Animal Health Laboratories, Department of Agriculture, Baron-Hay Court, South Perth 6151, \\ Western Australia
}

\begin{abstract}
Haplosporidium sp. is described from rock oysters Saccostrea cuccullata Born, 1778 experiencing epizootics on the northwestern coast of Western Australia. All stages were observed as focal infections in the connective tissue of the gills, or as disseminated infections in the mantle and around digestive diverticulae. Haplosporidium sp. occurred between epithelial cells of the gut, in focal lesions in the gills, but not in the epithelium of the digestive diverticulae, and sporulation was confined to the connective tissue. Plasmodia developed into sporonts and sporocysts in a loose syncytium that gave rise to binucleate and uninucleate sporoblasts from which spores developed. Spores were flask-shaped, 5.6-6.7 × 3.3-4.0 $\mu \mathrm{m}$, with a characteristic operculum, a few filamentous wrappings and rod-like structures in the posterior sporoplasm. Mature spores had a wall comprising inner (90 nm wide), middle (30 nm wide) and outer (130 nm wide) layers, and a surface coat of microtubules giving them a furry appearance. Oysters with empty gonad follicles were most heavily infected, and oyster condition and mortality appeared to be related to degree of infection.
\end{abstract}

KEY WORDS: Rock oysters · Saccostrea cuccullata $\cdot$ Haplosporidian $\cdot$ Haplosporidium $\cdot$ Minchinia Epizootics · Histopathology · Ultrastructure

\section{INTRODUCTION}

Protozoans currently recognized as haplosporidians are a small phylum of obligate parasites that infect several invertebrate groups. They have received considerable attention because some species are pathogenic in commercially important shellfish. Haplosporidium nelsoni and $H$. costale, along with another alveolate protistan, Perkinsus marinus, have severely affected oyster (Crassostrea virginica) fisheries in the eastern United States. H. nelsoni was first reported in association with C. virginica mortalities in Delaware Bay in 1957 (Haskin et al. 1966), and in Chesapeake Bay in

${ }^{*}$ Present address: National Centre for Disease Investigation, Ministry of Agriculture and Forestry (MAF) Operations, PO Box 40-742, Upper Hutt, New Zealand.

E-mail: hinem@maf.govt.nz
1959. Molecular evidence shows that $H$. nelsoni is conspecific with a similar Haplosporidium sp. in C. gigas from Japan (Friedman et al. 1991, Friedman 1996) and Korea (Kern 1976), and that it was introduced into California (Friedman 1996) in C. gigas from those countries (Burreson et al. 2000). H. nelsoni, or a very similar parasite, has also been introduced into France in $C$. gigas (Renault et al. 2000). A dissimilar Haplosporidium sp. has also been reported from C. gigas in France (Comps \& Pichot 1991). Unidentified stages of haplosporidians in flat oysters Ostrea edulis in Europe (Pichot et al. 1979, Bachère \& Grizel 1983, Bonami et al. 1985) may be those of $H$. armoricanum, which infects O. edulis in France (Cahour et al. 1980), the Netherlands (van Banning 1977), Spain (Azevedo et al. 1999), and $O$. angasi introduced into France (Bachère et al. 1987). 
Spores of the haplosporidian genera Minchinia and Haplosporidium are characterised by a distinctive operculum. The criteria for distinguishing Minchinia from Haplosporidium have altered many times (Marchand \& Sprague 1979, Azevedo 1984, La Haye et al. 1984, McGovern \& Burreson 1990, Azevedo et al. 1999), but are here taken to be the possession of taillike epispore cytoplasm extensions (ECE) in Minchinia spp. (McGovern \& Burreson 1990, Comps \& Tigé 1997, Azevedo et al. 1999, Azevedo 2001), and the possession of filaments or ribbon-like ornaments in the epispore cytoplasm that are wrapped around the spore in
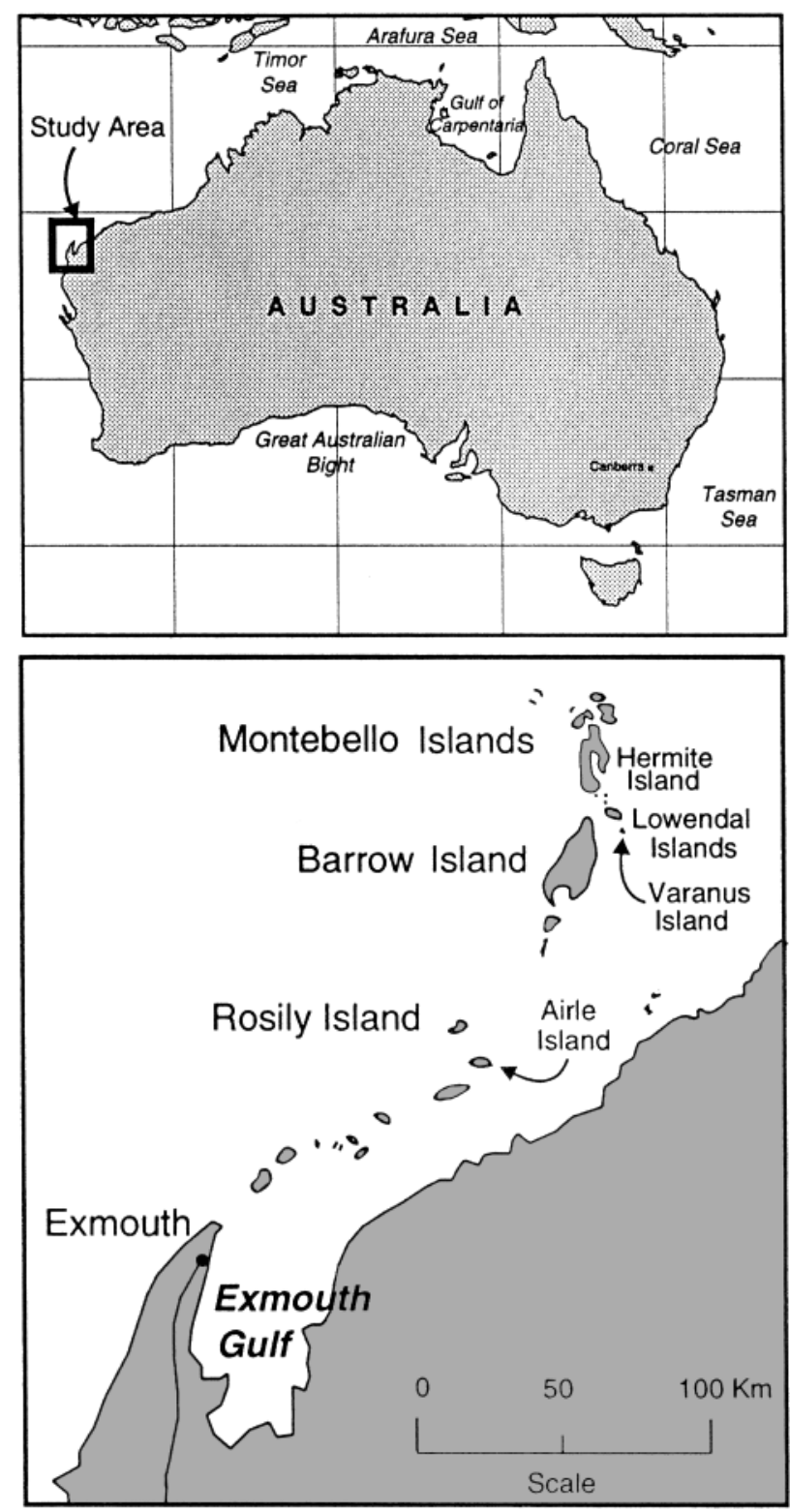

Fig. 1. Locations of sampling sites on the northwest coast of Western Australia
Haplosporidium spp., and which derive from the spore wall (Azevedo 1984, Azevedo et al. 1999).

Unquantified mortalities among rock oysters were first recognised by energy companies on the Northwest Gas Shelf of Western Australia, in the early 1990s. The companies subsequently submitted samples for diagnosis and research. This paper reports a previously undescribed haplosporidian associated with these mortalities, compares the haplosporidian with similar haplosporidians identified in other oyster species, and discusses their inter-relationships.

\section{MATERIALS AND METHODS}

During 1993 and 1994, 791 blacklip rock oysters Saccostrea cuccullata, 808 Sydney rock oysters S. glomerata (see Table 1 \& Fig. 1) and 106 tropical rock oysters $S$. echinata were sampled along the north coast of Western Australia. The oysters were opened and wet smears were prepared from the digestive gland. A standard section through the digestive gland, gills, labial palps and mantle, was fixed in Davidson's fixative, and stained with haematoxylin and eosin, or Ziehl-Neelsen's acid-fast stain with Loeffler's methylene blue as counterstain, or Ziehl's carbol fuchsin (Farley 1965). Small pieces of digestive gland from heavily infected oysters were fixed in $2.5 \%$ glutaraldehyde in $0.22 \mu \mathrm{m}$-filtered seawater for transmission electron microscopy (TEM). Samples for TEM were post-fixed for 1.0 to $1.5 \mathrm{~h}$ in $1 \% \mathrm{OsO}_{4}$ in $0.1 \mathrm{M}$ phosphate buffer, $\mathrm{pH}$ 7.2. Semi-thin sections were stained with $1 \%$ toluidine blue and $1 \%$ sodium tetraborate in distilled water for $20 \mathrm{~s}$ at $60^{\circ} \mathrm{C}$. Ultrathin sections were stained with $2 \%$ uranyl acetate for $10 \mathrm{~min}, 5 \%$ lead citrate for 5 to 6 min, and examined on a Philips CM10 transmission electron microscope.

Attempts were made to sample more oysters, but the area concerned is harsh and remote, requiring access by helicopter, and the attempts were unsuccessful. Following the development of a sensitive and specific probe for Haplosporidium nelsoni by Burreson et al. (2000), further attempts were made to sample oysters, but infected oysters could not be found (Dr Brian Jones pers. comm).

\section{RESULTS}

\section{Prevalence, gross signs and infection pattern}

A haplosporidian parasite occurred in the connective tissue of Saccostrea cuccullata, but not of S. glomerata, around the islands off the northwest of Australia (Table 1, Fig. 1). Further east, around the Dampier Archipel- 
ago, 4 of $430(0.9 \%)$ of $S$. cuccullata and 0 of $117(0.0 \%)$ S. glomerata were infected, but 33 S. cuccullata, 8 S. glomerata and 12 S. echinata from King Sound, and 94 $S$. echinata from Darwin Harbour and Bynoe Harbour were not infected (see Hine \& Thorne 2000 for locations). It must be noted that $S$. glomerata were only sampled from sites where $S$. cuccullata were also uninfected. The irregular frequency of sampling did not allow discrimination of seasonal patterns of infection by the haplosporidian.

Infected oysters varied in appearance, from oysters that appeared normal to oysters with meat of one-third normal size. The digestive gland was light brown and watery due to the absence of gonadal tissue overlying the digestive tissue. Overall $27 \%$ of male oysters, $23 \%$ of female oysters and $45 \%$ of oysters with empty gonad follicles were infected. Spores were present in $4 \%$ of infected male oysters, $13 \%$ of infected female oysters, and $59 \%$ of infected oysters with empty gonad follicles. Of 26 Saccostrea cuccullata from the Montebello Islands, 1 was infected with Marteilia lengehi, and of 44 S. cuccullata from East Lewis Island, Dampier Archipelago, 1 was systemically infected with Perkinsus sp., otherwise no other potentially serious infections were present.

\section{Histopathology}

Parasite stages usually occurred in focal lesions in connective tissue of the gills (Fig. 2), or as disseminated infections in connective tissue of the mantle and around digestive diverticulae (Fig. 3). Binucleate or multinucleate plasmodia, containing 2 to 25 nuclei in section, occurred in connective tissue (Fig. 4) and between (Fig. 5), but not in, epithelial cells of the main digestive tract, and not in the epithelium of digestive diverticulae. Some multinucleate stages were shaped like round or ovoid rings (Fig. 6). Assuming that binucleate and tetranucleate forms precede multinucleate stages, early infection occurred in the connective tissue of the gills, mantle and around the main digestive tract, from which infection became disseminated. Hyalinocytes were abundant in tissues heavily infected with plasmodia, but phagocytosis of plasmodia was rarely observed. Brown cells were numerous among plasmodia in connective tissue, but did not appear to attach to or phagocytose the parasite.

Sporulation was confined to connective tissue (Fig. 7), in which cells containing indistinct nuclei appeared to develop into a loose syncytium comprising cytoplasm with 1 or 2 nuclei of unequal size (Table 2). Flask-shaped spores developed asynchronously in these syncytia, forming spore clusters (Fig. 7). In heavily infected oysters, plasmodia, syncytia, sporocysts
Table 1. Prevalence of Haplosporidium sp. in Saccostrea cuccullata and Saccostrea glomerata along the north coast of Western Australia. ne: not examined; na: not applicable

\begin{tabular}{|lcccc|}
\hline Location & \multicolumn{2}{c}{$\begin{array}{c}\text { Saccostrea } \\
\text { cuccullata } \\
\text { No. }\end{array}$} & \multicolumn{2}{c|}{$\begin{array}{c}\text { Saccostrea } \\
\text { glomerata }\end{array}$} \\
& $\begin{array}{c}\text { No. } \\
\text { infected }\end{array}$ & $\begin{array}{c}\% \\
\text { infected }\end{array}$ & infected & infected \\
\hline Carnarvon & $0 / 22$ & 0.0 & $0 / 758$ & 0.0 \\
Exmouth Gulf & $0 / 76$ & 0.0 & $0 / 50$ & 0.0 \\
Barrow Island & $0 / 103$ & 0.0 & ne & na \\
Airlie Island & $26 / 211$ & 12.3 & ne & na \\
Rosily Island & $1 / 31$ & 3.2 & ne & na \\
Varanus Island & $90 / 322$ & 28.0 & ne & na \\
Montebello Islands & $4 / 26$ & 15.4 & ne & na \\
Total & $121 / 791$ & 15.3 & $0 / 808$ & 0.0 \\
& & & & \\
\hline
\end{tabular}

and spore clusters occupied $>50 \%$ of the connective tissue in section. Even in these infections, there was little if any haemocytic infiltration in response to sporulation, but brown cells were abundant at these sites.

\section{Electron microscopy}

Development appeared to occur by enlargement of plasmodia to multinucleate sporonts, which changed to sporocysts with cytoplasmic cleavage around individual nuclei, forming a syncytium containing sporoblasts and spores.

Plasmodia were distinguished by the presence of haplosporosomes and unmodified plasmalemma, and

Table 2. Haplosporidium sp. infecting Saccostrea cuccullata. Dimensions of the cells and their nuclei, each based on 50 measurements except TEM of plasmodia $(n=12)$. LM: light microscopy; TEM: transmission electron microscopy

\begin{tabular}{|lcl|}
\hline Stage/organelle & Method & \multicolumn{1}{c|}{ Dimensions } \\
\hline Plasmodium & LM & $6.3-15.4 \mu \mathrm{m}$ \\
Plasmodium & TEM & $4.0-4.5 \times 4.0-5.0 \mu \mathrm{m}$ \\
Plasmodial nuclei & TEM & $1.3-1.5 \mu \mathrm{m}$ \\
Sporonts & LM & $17.0-22.5 \mu \mathrm{m}$ \\
Sporonts & TEM & $7.0-29.7 \times 4.6-21.8 \mu \mathrm{m}$ \\
Sporont syncytium & LM & $20.0-31.0 \mu \mathrm{m}$ \\
Spore clusters & LM & $28.0-31.8 \mu \mathrm{m}$ \\
Sporont nuclei & TEM & $1.7-2.4 \mu \mathrm{m}$ \\
Uninucleate sporoblasts & TEM & $4.5-5.0 \times 3.64 .3 \mu \mathrm{m}$ \\
Uninucleate sporoblast & TEM & $2.3-3.0 \mu \mathrm{m}$ \\
nuclei & & \\
Binucleate sporoblasts & TEM & $6.0-6.2 \times 3.7-5.8 \mu \mathrm{m}$ \\
Early spores & TEM & $6.3-6.7 \times 3.7-4.1 \mu \mathrm{m}$ \\
(without operculum) & & \\
Early spore nuclei & TEM & $2.2-2.4 \mu \mathrm{m}$ \\
Mature spores & TEM & $5.6-6.7 \times 3.3-4.0 \mu \mathrm{m}$ \\
Mature spore nuclei & TEM & $1.8-2.3 \mu \mathrm{m}$ \\
& & \\
\hline
\end{tabular}


were rarely found in TEM preparations. They were irregular in outline and diplokaryotic, with the 2 nuclei separated by dark material, $50 \mathrm{~nm}$ across (Fig. 8, Table 2). Each nucleus had a single round eccentric nucleolus. Mitochondria with oval cristae and sparse smooth endoplasmic reticulum (sER) occurred in the cytoplasm. Haplosporosomes were pleomorphic, being rod-like, $50-67 \times 330 \mathrm{~nm}$ long and round in cross-section, ovoid to spherical $100-150 \mathrm{~nm}$ across, or small spherical and dense $60-70 \mathrm{~nm}$, with a poorly defined bipartite sub-structure.

Sporonts and sporocysts developed from plasmodia, and were distinguished by having few or no haplosporosomes and a layer of dark material, 27-36 nm

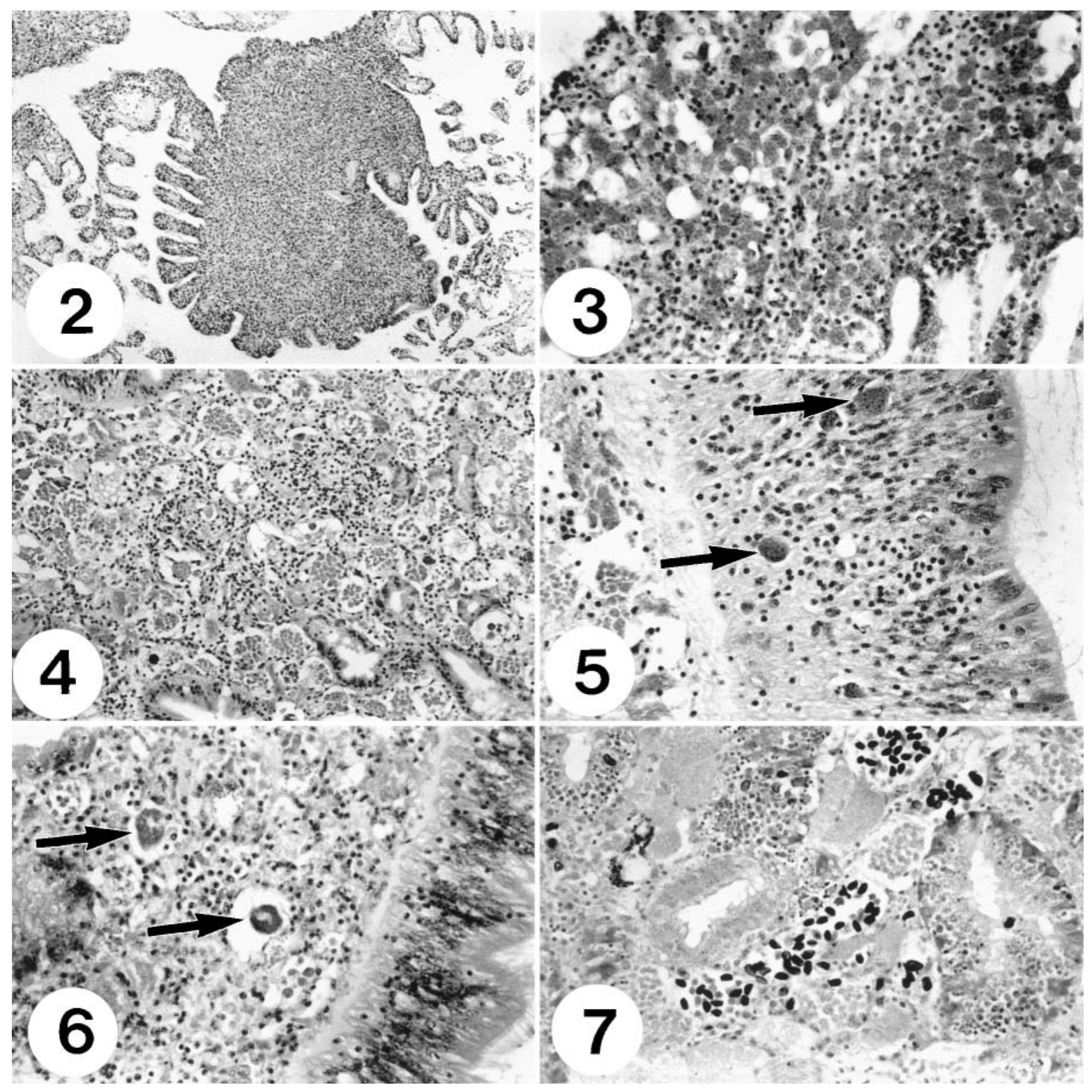

Figs. 2 to 7. Occurrence of Haplosporidium sp. in Saccostrea cuccullata. Light microscope histopathology. Fig. 2. Section through the gills showing a focal lesion, in which the connective tissue is packed with plasmodia $(\times 75)$. Fig. 3. Occurrence of several developmental stages in the connective tissue of the digestive gland, around digestive diverticulae and ducts $(\times 210)$. Fig. 4 . Multinucleate plasmodia and haemocytes in the digestive gland $(\times 190)$. Fig. 5. Multinucleate plasmodia (arrows) between the epithelial cells of the digestive tract $(\times 270)$. Fig. 6. Two Multinucleate plasmodia lying in clears spaces (arrows), showing ringlike configuration $(\times 300)$. Fig. 7. Ziehl-Nielsen stained section in which the spores stain strongly, showing their occurrence around, but not within, digestive tubules $(\times 340)$ 


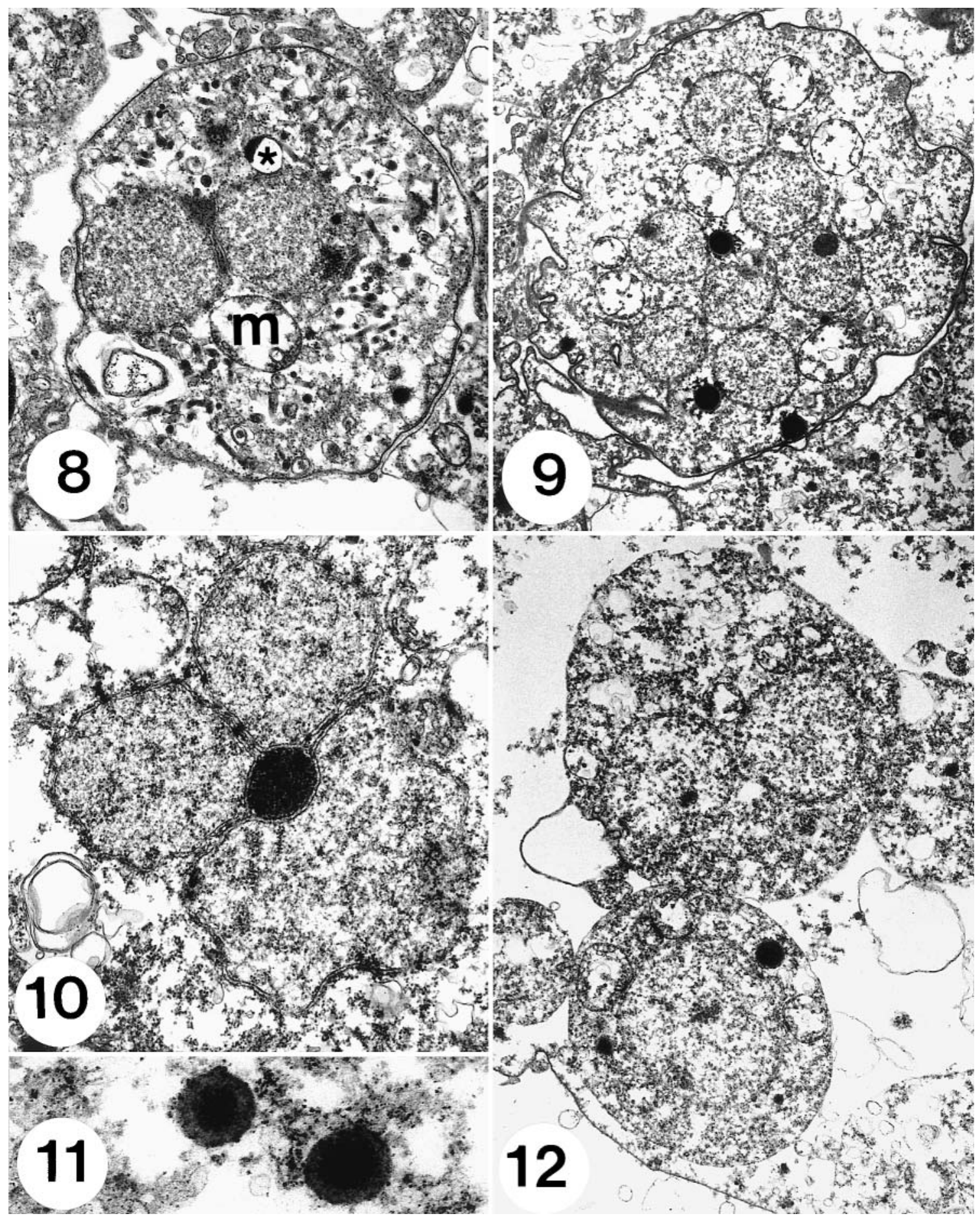

Figs. 8 to 12. Haplosporidium sp. infecting Saccostrea cuccullata: TEM of plasmodia, sporonts, sporocysts and sporoblasts. Fig. 8. Diplokaryotic plasmodium showing the dark material between the nuclei, elongated haplosporosomes, mitochondria (m) and lipid droplets $(*)(\times 16475)$. Fig. 9. Sporont with 7 nuclei showing the dense plasma membrane, lipid droplets, and lack of haplosporosomes $(\times 7440)$. Fig. 10. Sporont nuclei showing the dense material in shallow indentations of the nuclear membrane $(\times 21635)$. Fig. 11. Sporont haplosporosomes lacking a distinct internal membrane $(\times 63700)$. Fig. 12. Uninucleate and binucleate sporoblasts lacking a dense plasma membrane, and haplosporosomes $(\times 9210)$ 
wide, on the plasma membrane, which bore short pseudopodia containing actin-like filaments. Sporonts contained 2 to 13 spherical nuclei/section, with a single nucleolus, which were often grouped as diplo-, tetra-, and poly-karya (Fig. 9, Table 2) enclosing dense granular masses that occupied shallow indentations on the nuclear surface (Fig. 10). Dense material, $50 \mathrm{~nm}$ across, also occurred between closely apposed surfaces of these tightly grouped nuclei. Nuclear divisions and mitotic spindles were not observed. The cytoplasm comprised ragged mitochondria, a little sER and several lipid droplets. In multinucleate sporonts, nuclei were separate and distributed throughout the cytoplasm. The few haplosporosomes observed were spherical and dense (<120 nm across; Fig. 11).

Uninucleate and larger binucleate sporoblasts were distinguished from sections in which sporonts contained 1 or 2 nuclei by the lack of a thickened plasma membrane around the sporoblasts (Fig. 12, Table 2). Nuclear divisions were not observed, nor were the early stages of sporulation.

The earliest observed spore stages, characterised by presence of a spore wall (Fig. 13) and operculum developing in the episporoplasm, were ovoid, with a single nucleus, a wall 76-95 nm wide, and a few spherical dense vesicles (DVs) $140-178 \mathrm{~nm}$ in diameter (Table 2). Maturing spores were ovoid, with a wall 160-202 nm across composed of very fine concentric laminations in 3 layers: inner dense, $25-40 \mathrm{~nm}$; middle lucent, $19-33 \mathrm{~nm}$; outer dense, $110-133 \mathrm{~nm}$ across. The wall was sometimes thickened posteriorly. The spore wall appeared to develop at nodes which became joined to complete the wall. Microtubule-like structures, $22-25 \mathrm{~nm}$ across, with a periodicity of $20 \mathrm{~nm}$, occurred on the outside of the spore wall at the interface with episporoplasm. Sections through surface filaments, which may arise from a thickened portion of the posterior spore wall (Fig. 14), were only observed as 1 to 2 partial filaments around $<2 \%$ of spores.

An anterior spherule appeared to produce DVs (Fig. 15) that were numerous throughout the sporoplasm, spherical, 159-228 nm in diameter, and which sometimes developed an internal membrane to form spherical haplosporosomes $153-180 \mathrm{~nm}$ in diameter (Fig. 15). The nucleus was spherical to irregular in shape, situated equatorially, and near it were spherical aggregations of dense granular material around which DVs were clustered (Fig. 16, Table 2). Bundles of microfilaments were seen in some sporoplasms (Fig. 16), and lipid droplets were commonly observed (Fig. 15), often bordered by 1 to 2 cisternae of sER. A lipid body was frequently observed in the episporoplasm adjacent to the middle of the spore (Figs. 15 \& 16).

The operculum appeared to initially develop in the episporoplasm as 2 thin plates, 3.0-3.9 $\mu \mathrm{m}$ long, bear- ing a hinge at one side. Later the lower plate became attached to the spore wall at the anterior orifice. The inner dense layer of the 3 layers comprising the wall was reduced in the operculum, being $8-10 \mathrm{~nm}$, with a middle lucent layer of $20-25 \mathrm{~nm}$, and the outer dense layer reducing from $120-125 \mathrm{~nm}$ to $45 \mathrm{~nm}$ in the operculum (Fig. 17).

Mature spores had a wall $250 \mathrm{~nm}$ thick divided into 3 layers: inner dense, $90 \mathrm{~nm}$; middle lucent, $30 \mathrm{~nm}$; and outer dense, $130 \mathrm{~nm}$ across. After loss of the episporoplasm, the outer spore wall bore many microtubules $25 \mathrm{~nm}$ in diameter that showed no orientation or coalescence and were at least $1.25 \mu \mathrm{m}$ long (Fig. 17). The operculum had a similar structure to the spore wall and was also coated with unorientated microtubules. Rod-like structures $(695 \times 50 \mathrm{~nm})$ developed posteriorly in maturing spores, and were grouped near inversions of the spore wall or at the posterior pole of mature spores (Fig. 18). Similar rodlike structures $(950 \times 100 \mathrm{~nm})$ remained inside empty spores, which appeared to have exsporulated, as a uninucleate stage resembling the sporoplasm was often adjacent to the empty spore.

Ultrastructural observations on the inflammatory exudate showed it to be composed of $>80 \%$ hyalinocytes, $<5 \%$ granulocytes, and unidentified immature haemocytes.

\section{DISCUSSION}

Prevalence of infected oysters is not a good indicator of the severity of disease unless the temporal aspects of disease progression and number of freshly dead oysters can be determined. Despite this, the data suggest that infection was more prevalent in the west (Airlie, Varanus, Montebello and Lowendell Islands, than in the east (Dampier Archipelago, King Sound). Few oysters were lightly infected, and disease appeared to be progressive and fatal. The area concerned is remote, harsh, and sparsely populated. Saccostrea cuccullata is not considered commercially important, and there have been no known movements of oysters into or out of the area. The mortalities therefore appear to be a natural event, unassociated with human activity. No other infections were observed that might account for the mortalities. No other dead and dying aquatic organisms were observed, suggesting mortalities were not due to environmental changes. The higher prevalence of infection and more common sporogenesis in oysters with empty gonad follicles may have been due to loss of condition after spawning increasing the susceptibility to infection. Alternatively, infection may reduce the host energy budget causing reduction in, or cessation of, gametogenesis, similar to that reported in 

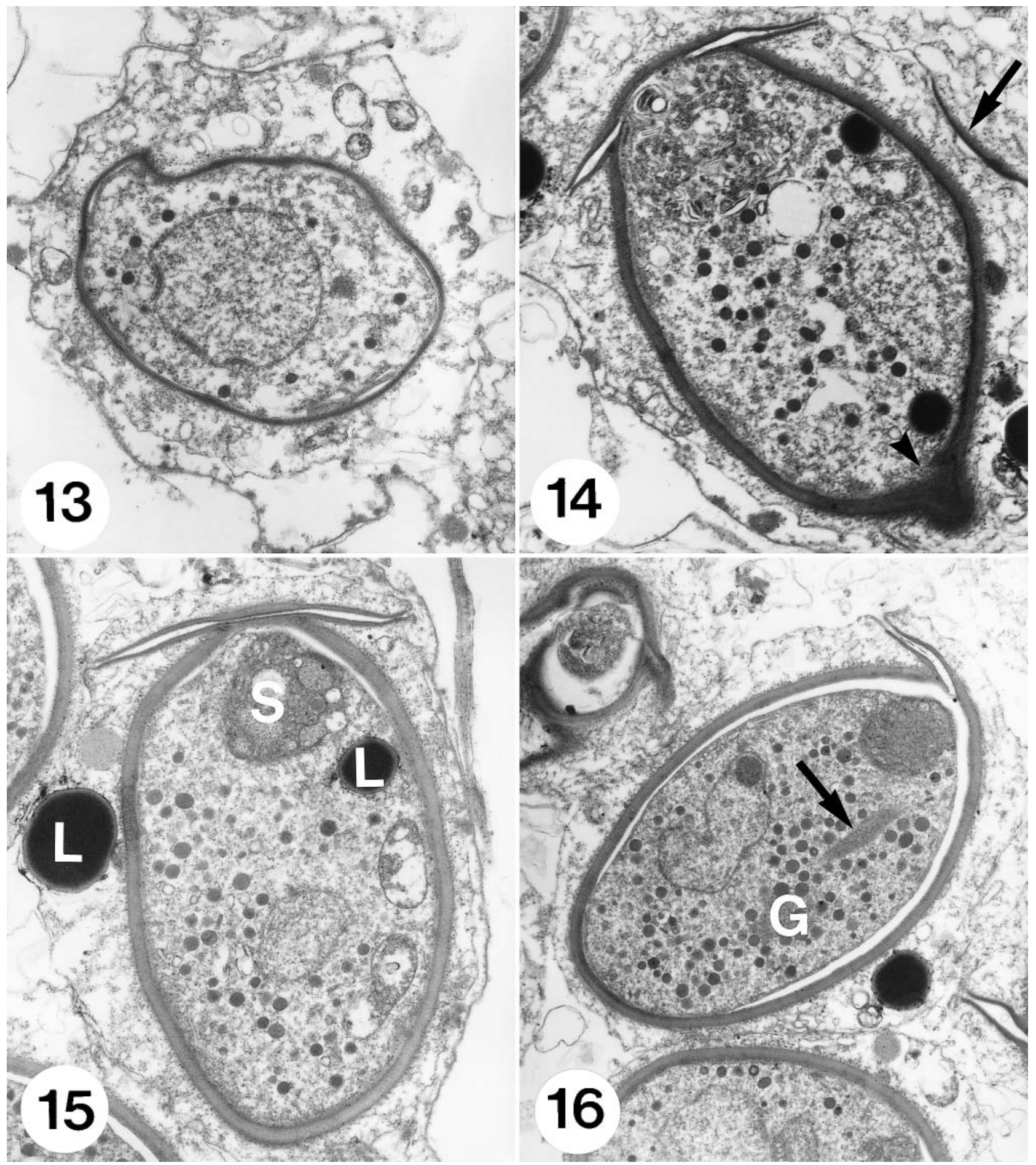

Figs. 13 to 16. Haplosporidium sp. infecting Saccostrea cuccullata: spore formation. Fig. 13. Developing spore showing spore wall, central round nucleus and a few sperical dense vesicles, DVs $(\times 12870)$. Fig. 14. Spore showing posterior thickening of the spore wall (arrowhead) and a filament in the episporoplasm (arrow) $(\times 13125)$. Fig. 15. Spore with an anterior spherule (S) containing bodies resembling DVs. Prominent lipid droplets $(\mathrm{L})$ are present $(\times 163 \overline{60})$. Fig. 16 . Spore containing a bundle of micro- 

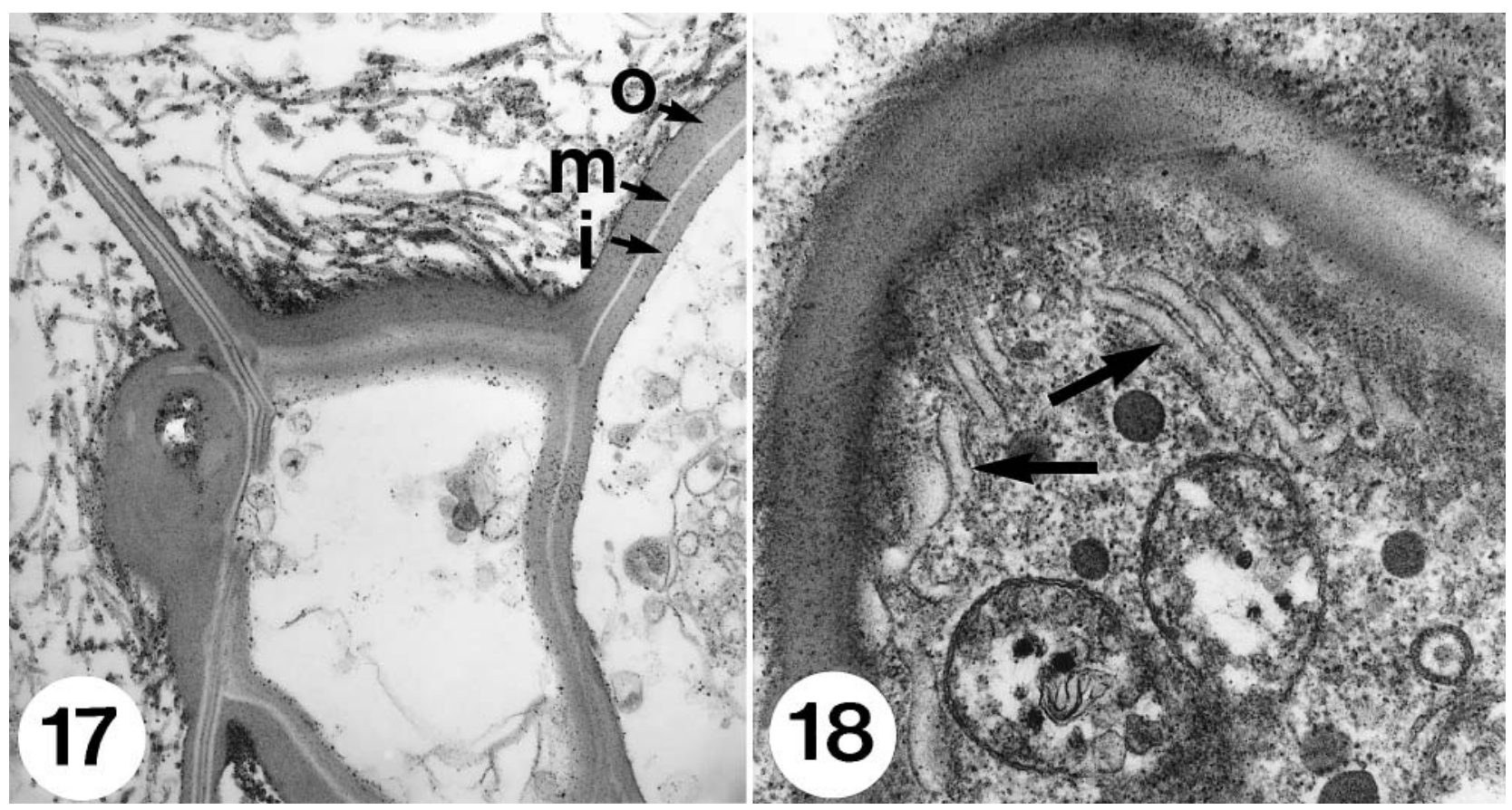

Figs 17 to 18. Haplosporidium sp. infecting Saccostrea cuccullata: spores. Fig. 17. Anterior of a mature spore showing the inner (i), middle $(\mathrm{m})$ and outer (o) layers of the operculum and wall, and surface microtubules $(\times 28815)$. Fig. 18. Posterior of spore showing rodlike structures (arrows) $(\times 42890)$

Haplosporidium nelsoni infections of Crassostrea virginica (Barber et al. 1988, Ford \& Figueras 1988, Ford et al. 1990).

Comparison with other haplosporidian studies in the literature is difficult because of inconsistencies in terminology (particularly the use of 'plasmodia' and 'sporocysts') for multinucleate sporonts, and because spore dimensions vary between fresh smears, sections in light and electron microscopy and re-embedding of tissues for TEM from paraffin wax blocks. Also, as in this study, most observations have been made on maturing (but immature) spores, as the contents of mature spores were often lost or, when present, were often very dense. Despite this, differences in spore size and tissue tropism can be discerned (Table 3).

The species described here was difficult to place in either of the genera Haplosporidium or Minchinia with any certainty. The surface microtubules that

Table 3. Haplosporidium spp. reported from oysters, connective tissue, CT and digestive tubule epithelium, DTE. (+: present; -: absent); (f): fresh spores, (s): in section; ng: not given

\begin{tabular}{|c|c|c|c|c|c|}
\hline Species & Host & CT & DTE & Spore dimensions $(\mu \mathrm{m})$ & Source \\
\hline H. nelsoni & Crassostrea virginica & + & + & $8.1 \times 5.5$ & Perkins (1968) \\
\hline Haplosporidium sp. & C. gigas & + & + & $\begin{array}{c}6.7 \times 5.1 \\
6-8 \times 5-6\end{array}$ & Friedman et al. (1991) \\
\hline Haplosporidium sp. & C. gigas & + & + & $\begin{aligned} 6.3 & \times 4.6 \\
5.0-8.0 & \times 4.0-6.0\end{aligned}$ & Kern (1976) \\
\hline H. costale & C. virginica & + & - & $4.3 \times 3.3$ & Perkins (1969) \\
\hline Haplosporidium sp. & C. gigas & + & - & $4.8 \times 3.4$ & Comps \& Pichot (1991) \\
\hline Haplosporidium sp. & C. gigas & + & - & $\mathrm{ng}$ & Katkansky \& Warner (1970) \\
\hline H. armoricanum & Ostrea edulis & + & - & $\begin{array}{l}5.0-5.5 \times 4.0-4.5^{\mathrm{f}} \\
4.0-4.5 \times 3.0-4.0^{\mathrm{s}}\end{array}$ & van Banning (1977) \\
\hline H. armoricanum & O. edulis & $\mathrm{ng}$ & $\mathrm{ng}$ & $\begin{array}{l}4.5-5.0 \times 3.5-4.5^{\mathrm{f}} \\
3.0-4.0 \times 2.5-3.5^{\mathrm{s}}\end{array}$ & Pichot et al. (1979) \\
\hline H. armoricanum & O. edulis & + & - & $4.0-6.0 \times 2.5-4.0$ & Bachère \& Grizel (1983) \\
\hline H. armoricanum & O. angasi & + & - & $4.0-5.0 \times 2.5-4.0$ & Bachère et al. (1987) \\
\hline Haplosporidium sp. & Pinctada maxima & + & - & $6.7-7.7 \times 3.8-4.3$ & Hine \& Thorne (1998) \\
\hline Haplosporidium sp. & Saccostrea cuccullata & + & - & $5.6-6.7 \times 3.3-4.0$ & This study \\
\hline
\end{tabular}


appeared to derive from the episporoplasm resemble similar microtubules in epispore cytoplasmic vacuoles of Minchinia in crabs (Rosenfield et al. 1969, Perkins 1975). These may be seen aligned under the epispore plasma membrane in M. chitonis (Ball 1980), appear to enter the ECE as bundles of microtubules in M. teredinis (McGovern \& Burreson 1990), and form the support of ECE in Minchinia sp. from mussels (Mytilus galloprovincialis) (Comps \& Tigé 1997). However, in these latter cases the microtubules are aligned, and it is only in Haplosporidium ascidiarum from tunicates that similar unaligned microtubules have been reported (Ormières \& de Puytorac 1968). A recent study on $H$. ascidiarum suggests that the spore wall is assembled from similar filaments (Ciancio et al. 1999). Filaments have not been observed around H. ascidiarum (Azevedo et al. 1999, Ciancio et al. 1999), and it may therefore be a species of Minchinia. However, on the basis of rare observations suggesting that spore filaments may occur in this study, and that they derive from the spore wall (Fig. 14), the present species is tentatively placed in the genus Haplosporidium.

Haplosporidians are usually host genus-specific, and the other species described from oysters need to be considered (Table 3). Although the oyster genera Crassostrea and Saccostrea are closely related and sometimes used interchangeably, they are distinct genera (Brock 1990). Restriction of plasmodial and sporulation stages to connective tissue has been reported from all Haplosporidium spp. of ostreids (Table 3), except H. nelsoni (Perkins 1968, Kern 1976, Friedman et al. 1991, Friedman 1996, Renault et al. 2000), which infects epithelia as well as connective tissue.

The Haplosporidium sp. in Saccostrea cuccullata has spores similar in size to haplosporidians of Ostrea spp., including H. armoricanum (van Banning 1977, Cahour et al. 1980) (Table 3). The spores are smaller than those of H. nelsoni (Perkins 1968) from Crassostrea virginica, and from C. gigas in Japan (Friedman et al. 1991) and Korea (Kern 1976), but larger than spores of H. costale (Perkins 1969) in C. virginica, and Haplosporidium sp. in C. gigas from the French Mediterranean (Comps \& Pichot 1991) (Table 3). The species reported here also differs from $H$. nelsoni in its lack of plasmodial multivesicular bodies. There is also a dissimilarity between the rod-like and small dense haplosporosomes of Haplosporidium sp. plasmodia, and those of $H$. nelsoni (Perkins 1968). A specific probe for H. nelsoni (Stokes \& Burreson 1995) did not react with the Haplosporidium sp. described herein (Dr E. M. Burreson, Virginia Institute of Marine Science, pers. comm.). It has a closer similarity with $H$. costale in that both contain granular material in nuclear membrane indentations and free at the surface of plasmodial and sporont nuclei (Perkins 1969), but the rod-like haplosporosomes of Haplosporidium sp. from S. cuccullata are unlike the pyriform haplosporosomes of $H$. costale (Perkins 1969). The species reported herein differs from $H$. armoricanum in the appearance of haplosporosomes and large sporocysts (30 to $50 \mu \mathrm{m}$ ) with 100 to 150 nuclei in the latter species. It also differs from the Haplosporidium sp. infecting pearl oysters (Pinctada maxima: Pteriidae) on the same coast, in size (spores in P. maxima 6.7-7.7 $\times 3.8-4.3 \mu \mathrm{m}$, position of the nucleus in the spores, the presence of lipid droplets in the spore and epispore, the presence of rod-like structures in the posterior sporoplasm, and surface microtubules (Hine \& Thorne 1998).

The developmental stages observed here are similar in general detail to those reported from other Haplosporidium and Minchinia species (Perkins 1968, 1969, Marchand \& Sprague 1979, Ball 1980, Desportes \& Nashed 1983, La Haye et al. 1984, Hillman et al. 1990), except that the persistent mitotic spindle, division, and the nuclear fusion followed by enclosure of the sporoplasm by the episporoplasm (Desportes \& Nashed 1983) were not observed. However, the greater nuclear size of the earliest uninucleate sporoblasts $(2.3$ to $3.0 \mu \mathrm{m}$ ) than preceding ( 2.0 to $2.4 \mu \mathrm{m})$ or succeeding (2.2 to $2.4 \mu \mathrm{m})$ nuclei, may reflect fusion of the nuclei of a preceding binucleate stage, as in M. dentale (Desportes \& Nashed 1983). The rod-like structures at the periphery and posterior of the sporoplasm have not been previously reported. If the rod-like bodies in empty spores derive from them, they may have a function in expulsion of the sporoplasm.

Just as the haplosporidians of xanthid crabs may be a single species or closely related species (Perkins \& van Banning 1981), similarities may be seen between the Haplosporidium and Minchinia species of ostreids. Molecular evidence suggests that discrimination of Haplosporidium and Minchinia on the basis of the presence of tails, filaments, wrappings, ribbons, or other ornaments (Azevedo 1984) may be invalid (Flores et al. 1996). Even such phenotypic traits as spore formation itself may be unreliable. Recent studies suggest that, phylogenetically, Bonamia spp., for which spores are unknown, may lie between Haplosporidium and Minchinia (Carnegie et al. 2000, Hine et al. 2001), and it has even been suggested that $B$. ostreae may be placed in the genus Haplosporidium (Cochennec et al. 2000). Formal description of the species reported here must await clarification of the phylogeny of haplosporidian genera. Formal descriptions should be based on both molecular phylogeny, and the ultrastructure of phenotypes. 
Acknowledgements. We are grateful to Steve Arrow and his staff of the Arrow Pearling Company, Dr Lindsay Joll of the Fisheries Department, Western Australia, and Trevor Sweetman of Western Seafarms. Special thanks to Dr Shirley SlackSmith of the West Australian Museum for her expert identification of host species.

\section{LITERATURE CITED}

Azevedo C (1984) Ultrastructure of the spore of Haplosporidium lusitanicum sp. n. (Haplosporida, Haplosporidiidae), parasite of a marine mollusc. J Parasitol 70:358-371

Azevedo C (2001) Ultrastructural description of the spore maturation stages of the clam parasite Minchinia tapetis (Vilela, 1951) (Haplosporidia: Haplosporidiidae). Syst Parasitol 49:189-194

Azevedo C, Montes J, Corral L (1999) A revised description of Haplosporidium armoricanum, parasite of Ostrea edulis L. from Galicia, northwestern Spain, with special reference to the spore-wall filaments. Parasitol Res 85:977-983

Bachère E, Grizel H (1983) Mise en évidence d'Haplosporidium sp. (Haplosporida: Haplosporidiidae) parasite de l'huître plate Ostrea edulis. Rev Trav Inst Pêches Marit 46: 226-232

Bachère E, Chagot D, Tigé G, Grizel H (1987) Study of a haplosporidian (Ascetospora), parasitizing the Australian flat oyster Ostrea angasi. Aquaculture 67:266-268

Ball SJ (1980) Fine structure of the spores of Minchinia chitonis (Lankester, 1885) Labbé, 1896 (Sporozoa: Haplosporida), a parasite of the chiton, Lepidochitona cinereus. Parasitology 81:169-176

Barber BJ, Ford SE, Haskin HH (1988) Effects of the parasite MSX (Haplosporidium nelsoni) on oyster (Crassostrea virginica) energy metabolism. I. Condition index and relative fecundity. J Shellfish Res 7:25-31

Bonami JR, Vivarès CP, Bréhelin M (1985) Étude d'une nouvelle haplosporidie parasite de l'huître plate Ostrea edulis L.: morphologie et cytologie de différents stades. Protistologica 21:161-173

Brock V (1990) Intergeneric distances between Ostrea, Crassostrea, and Saccostrea, studied by means of crossed immuno-electrophoresis. Mar Ecol Prog Ser 68:59-63

Burreson EM, Stokes NA, Friedman CS (2000) Increased virulence in an introduced pathogen: Haplosporidium nelsoni (MSX) in the eastern oyster Crassostrea virginica. $\mathrm{J}$ Aquat Anim Health 12:1-8

Cahour A, Poder M, Balouet G (1980) Présence de Minchinia armoricana (Haplosporea, Haplosporida) chez Ostrea edulis d'origine francaise. CR Séances Soc Biol 174:359-368

Carnegie RB, Barber BJ, Culloty SC, Figueras AJ, Distel DL (2000) Development of a PCR assay for detection of the oyster pathogen Bonamia ostreae and support for its inclusion in the Haplosporidia. Dis Aquat Org 42:199-206

Ciancio A, Scippa S, Izzo C (1999) Ultrastructure of vegetative and sporulation stages of Haplosporidium ascidiarum from the ascidian Ciona intestinalis L. Eur J Protistol 35: 175-182

Cochennec N, Le Roux F, Berthe F (2000) Detection of Bonamia ostreae based on small subunit ribosomal probe. J Invertebr Pathol 76:26-32

Comps M, Pichot Y (1991) Fine spore structure of a haplosporidan parasitizing Crassostrea gigas: taxonomic implications. Dis Aquat Org 11:73-77

Comps M, Tigé G (1997) Fine structure of Minchinia sp., a haplosporidan infecting the mussel Mytilus galloprovincialis L. Syst Parasitol 38: 45-50
Desportes I, Nashed NN (1983) Ultrastructure of sporulation in Minchinia dentali (Arvy), an haplosporean parasite of Dentalium entale (Scaphopoda, Mollusca); taxonomic implications. Protistologica 19:435-460

Farley CA (1965) Acid-fast staining of haplosporidian spores in relation to oyster pathology. J Invertebr Pathol 7: 144-147

Flores BS, Siddall ME, Burreson EM (1996) Phylogeny of the Haplosporidia (Eukaryota: Alveolata) based on small subunit ribosomal RNA gene sequence. J Parasitol 82: 616-623

Ford SE, Figueras AJ (1988) Effects of sublethal infection by the parasite Haplosporidium nelsoni (MSX) on gametogenesis, spawning, and sex ratios of oysters in Delaware Bay. Dis Aquat Org 4:121-133

Ford SE, Figueras AJ, Haskin HH (1990) Influence of selective breeding, geographic origin, and disease on gametogenesis and sex ratios of oysters, Crassostrea virginica, exposed to the parasite Haplosporidium nelsoni (MSX). Aquaculture 88:285-301

Friedman CS (1996) Haplosporidian infections of the Pacific oyster, Crassostrea gigas (Thunberg), in California and Japan. J Shellfish Res 15:597-600

Friedman CS, Cloney DF, Manzer D, Hedrick RP (1991) Haplosporidiosis of the Pacific oyster, Crassostrea gigas. J Invertebr Pathol 58:367-372

Haskin HH, Stauber LA, Mackin JA (1966) Minchinia nelsoni n. sp. (Haplosporida, Haplosporidiidae): causative agent of the Delaware Bay oyster epizootic. Science 153: $1414-1416$

Hillman RE, Ford SE, Haskin HH (1990) Minchinia teredinis n.sp. (Balanosporida, Haplosporidiidae), a parasite of teredinid shipworms. J Protozool 37:364-368

Hine PM, Thorne T (1998) Haplosporidium sp. (Haplosporidia) in hatchery-reared pearl oysters, Pinctada maxima (Jameson, 1901), in north Western Australia. J Invertebr Pathol 71: 48-52

Hine PM, Thorne T (2000) A survey of some parasites and diseases of several species of bivalve mollusc in northern Western Australia. Dis Aquat Org 40:67-78

Hine PM, Cochennec-Laureau N, Berthe FCJ (2001) Bonamia exitiosus n. sp. (Haplosporidia) infecting flat oysters Ostrea chilensis in New Zealand. Dis Aquat Org 47:63-72

Katkansky SC, Warner RW (1970) Sporulation of a haplosporidan in a Pacific oyster (Crassostrea gigas) in Humboldt Bay, California. J Fish Res Board Can 27:1320-1321

Kern GC (1976) Sporulation of Minchinia sp. (Haplosporida, Haplosporidiidae) in the Pacific oyster Crassostrea gigas (Thunberg) from the Republic of Korea. J Protozool 23: 498-500

La Haye CA, Holland ND, McLean N (1984) Electron microscopic study of Haplosporidium comatulae n. sp. (phylum Ascetospora: class Stellatosporea), a haplosporidian endoparasite of an Australian crinoid, Oligometra serripinna (phylum Echinodermata). Protistologica 20:507-515

Marchand J, Sprague V (1979) Ultrastructure de Minchinia cadomensis sp.n. (Haplosporida) parasite du décapode Rhithropanopeus harrisii tridentatus Maitland dans le canal de Caen à la mer. J Protozool 26:179-185

McGovern ER, Burreson EM (1990) Ultrastructure of Minchinia sp. spores from shipworms (Teredo spp.) in the western north Atlantic, with a discussion of taxonomy of the Haplosporidiidae. J Protozool 37:212-218

Ormières R, de Puytorac P (1968) Ultrastructure des spores de l'haplosporidie Haplosporidium ascidiarium endoparasite du Tunicier Sydnium elegans Giard. CR hebd Séances Acad Sci Paris (Sér D) 266:1134-1136 
Perkins FO (1968) Fine structure of the oyster pathogen Minchinia nelsoni (Haplosporida, Haplosporidiidae). J Invertebr Pathol 10:287-307

Perkins FO (1969) Electron microscope studies of sporulation in the oyster pathogen, Minchinia costalis (Sporozoa: Haplosporida). J Parasitol 55:897-920

Perkins FO (1975) Fine structure of Minchinia sp. (Haplosporida) sporulation in the mud crab, Panopeus herbstii. Mar Fish Rev 37:46-60

Perkins FO, van Banning P (1981) Surface ultrastructure of spores in three genera of Balanosporida, particularly in Minchinia armoricana van Banning, 1977 - the taxonomic significance of spore wall ornamentation in the Balanosporida. J Parasitol 67:866-874

Pichot Y, Comps M, Deltreil JP (1979) Recherches sur Haplosporidium sp. (Haplosporida: Haplosporidiidae) parasite

Editorial responsibility: Albert Sparks,

Seattle, Washington de l'huître plate Ostrea edulis. Rev Trav Inst Pêches Marit 43:405-408

Renault T, Stokes NA, Chollet B, Cochennec N, Berthe F, Gérard A, Burreson EM (2000) Haplosporidiosis in the Pacific oyster Crassostrea gigas from the French Atlantic coast. Dis Aquat Org 42:207-214

Rosenfield A, Buchanan L, Chapman GB (1969) Comparison of the fine structure of spores of three species of Minchinia (Haplosporida, Haplosporidiidae). J Parasitol 55: 921-941

Stokes NA, Burreson EM (1995) A sensitive and specific DNA probe for the oyster pathogen Haplosporidium nelsoni. J Eukaryot Microbiol 42: 350-357

van Banning P (1977) Minchinia armoricana sp. nov. (Haplosporida), a parasite of the European flat oyster, Ostrea edulis. J Invertebr Pathol 30:199-206

Submitted: October 11, 2001; Accepted: April 26, 2002

Proofs received from author(s): August 12, 2002 